\title{
KEPEMIMPINAN TRANSAKSIONAL DAN KEMAJUAN USAHA KELOMPOK PEDAGANG TANAMAN HIAS PADA MASA PANDEMI COVID-19
}

\section{Transactional Leadership and Business Progress of Ornamental Plant Traders Group during the Covid-19 Pandemic}

\author{
Dewa Ayu Kirana Puspita D.S, Lala M Kolopaking, dan Lukman Hakim
}

Departemen Sains Komunikasi dan Pengembangan Masyarakat, Fakultas Ekologi Manusia, IPB University, Dramaga Bogor 16680, Indonesia

*)E-mail: kirana_sudira@apps.ipb.ac.id; lalakolopaking@gmail.com; lukmanhakim@apps.ipb.ac.id

Diterima: 28-10-2021 | Disetujui: 03-01-22 | Publikasi online: 20-01-2022

\begin{abstract}
MSMEs tend to be closer to the community so the number is increasing every year. The Covid-19 pandemic caused some changes that forced people to stay at home. This led to a surge in interest and trends towards houseplants. Running an MSME group is inseparable from the leadership role. There are various leadership styles, one of which is transactional leadership This research aims to analyze the relationship of transactional leadership with business progress. The research method is conducted by quantitative approach through census methods and supported by qualitative data from in-depth interviews. The results of Spearman Rank correlation testing state that transactional leadership is significantly correlated with the progress of ornamental plant efforts. Trends and public interests also have an influence on business progress during the pandemic. In addition, the ethnicity of traders has a role in strengthening the leadership and position of ornamental traders in the bogor city ornamental plant market.
\end{abstract}

Keywords: Covid-19, Business Progress, Transactional Leadership, MSMEs.

\begin{abstract}
ABSTRAK
UMKM cenderung lebih dekat dengan masyarakat sehingga jumlahnya semakin bertambah tiap tahunnya. Pandemi Covid-19 menyebabkan beberapa perubahan yang memaksa masyarakat untuk tinggal di rumah. Hal ini menyebabkan lonjakan minat dan tren terhadap tanaman hias. Menjalankan kelompok UMKM tidak terlepas dari peran kepemimpinan. Terdapat berbagai macam gaya kepemimpinan salah satunya kepemimpinan transaksional. Penelitian ini bertujuan untuk menganalisis hubungan kepemimpinan transaksional dengan kemajuan usaha. Metode penulisan yang digunakan adalah pendekatan kuantitatif melalui metode sensus dan didukung data kualitatif dari hasil wawancara mendalam. Hasil dari pengujian korelasi Rank Spearman menyatakan bahwa kepemimpinan transaksional berkorelasi signifikan dengan kemajuan usaha tanaman hias. Tren dan minat masyarakat juga memiliki pengaruh terhadap kemajuan usaha selama masa pandemi. Selain itu, etnisitas pedagang memiliki peran dalam memperkuat kepemimpinan dan kedudukan para pedagang hias di pasar tanaman hias Kota Bogor.
\end{abstract}

Kata Kunci: Covid-19, Kepemimpinan Transaksional, Kemajuan Usaha, UMKM. 


\section{PENDAHULUAN}

UMKM cenderung bersifat resilien pada keadaan krisis atau bahkan mampu menjadi penyelamat di masa krisis. Berbeda dengan usaha besar yang cenderung mudah terguncang pada saat masa krisis. UMKM juga memiliki peran sebagai penampung tenaga kerja dan menjadi sumber penghasilan bagi masyarakat menengah kebawah (Nizar 2018). Masa pandemi Covid-19 telah menyebabkan berbagai krisis pada berbagai bidang, termasuk krisis dibidang ekonomi. Hal ini membuka peluang bagi para pelaku usaha UMKM untuk turut berperan menjadi penyelamat di masa krisis ini. Usaha tanaman hias sedang menjadi sorotan akhir-akhir ini. menurut Gunawan dan Sayaka (2020) Sejak pandemi Covid-19 omzet pedagang tanaman hias meningkat hingga 40 persen dari kondisi normal. Terdapat ketertarikan khusus kepada tanaman hias terutama tanaman hias yang cocok untuk disimpan di dalam ruangan. Kenaikan minat pada tanaman hias ini disebabkan oleh perubahan gaya hidup masyarakat yang sekarang lebih banyak menghabiskan waktunya di rumah. Banyaknya waktu luang menimbulkan minat masyarakat untuk menata taman dengan tanaman hias sebagai pelepas stress. Tingginya minat masyarakat terhadap tanaman hias menjadi potensi bagi pedagang tanaman hias untuk mengembangkan usahanya. Adanya fenomena naiknya minat masyarakat terhadap tanaman hias menimbulkan ketertarikan bagi penulis untuk melihat dari sisi pedagang tanaman hias.

Menjalankan suatu usaha tidaklah luput dari adanya peran kepemimpinan. Pemimpin yang baik tidak hanya memberi perintah saja kepada anggotanya tetapi turut mendorong anggota untuk melaksanakan pergerakan. Pemimpin cenderung memiliki karakteristik kuat yang dapat mendorong anggotanya untuk melaksanakan perubahan ke arah yang lebih baik dengan memberi contoh dan memotivasi anggotanya. Motivasi yang diberikan dapat menjadi pemicu bagi para anggota untuk terus berjalan maju mencapai tujuan. Tidak hanya sekedar memerintah atau memberi tugas, peran pemimpin adalah untuk memotivasi anggotanya untuk melaksanakan tugasnya, didukung oleh pernyataan dari Cote (2017) kepemimpinan adalah sebuah proses memberi inspirasi kepada bawahan atau pengikut agar pengikut dapat bekerja secara sukarela tanpa tekanan. Melaksanakan tugas tanpa adanya tekanan adalah hal yang menyenangkan, terutama jika seorang yang memimpin juga dapat menciptakan suasana yang nyaman. Hal ini mencerminkan peran penting kepemimpinan dalam mendorong dan memotivasi anggotanya untuk terus menjalankan usahanya.

Berdasarkan Epitropaki dan Martin (2013) pemimpin transaksional adalah sosok pemimpin yang mampu membuat ekspektasi kinerja yang jelas. Sikap tegas dan jelas dari sosok pemimpin dibutuhkan agar anggotanya dapat terpacu dalam menjalankan usahanya terutama pada keadaan unik seperti pandemi. Manusia memerlukan dorongan dan motivasi agar dapat mencapai tujuannya. Pemimpin transaksional pada umumnya gemar memberi motivasi bagi anggotanya agar anggotanya dapat mengejar tujuan yang sudah ditetapkan (Tyssen et al. 2014). Dorongan kuat dari ketua kelompok kemungkinan besar akan membantu anggota untuk terus bertahan mencapai tujuannya pada masa krisis ini. Anggota dengan jelas paham apa yang harus dilakukan dan apa konsekuensi dari perilakunya. Pemimpin dengan gaya transaksional cenderung berorientasi pada tujuan bersama. Pemimpin cenderung mengakui kebutuhan dan keinginan pengikut dengan imbalan atas pekerjaannya. Jika memenuhi proporsi kerjanya maka anggota dapat mendapatkan imbalan dari ketua, sebaliknya jika melakukan penyimpangan akan mendapat hukuman (Bass 1990). Kegiatan perdagangan yang orientasinya mencari keuntungan sangatlah cocok untuk menerapkan kepemimpinan transaksional dalam kelompok dagang yang memiliki tujuan jelas untuk mencari keuntungan.

\section{Rumusan Masalah}

Pada dasarnya kepemimpinan adalah strategi pemimpin untuk mempengaruhi anggotanya dalam mencapai tujuan bersama organisasi (Arifudin 2020). Terdapat berbagai perspektif untuk melihat kepemimpinan. Kepemimpinan transaksional menurut Andari (2019) adalah pendekatan kepemimpinan dimana pemimpin dengan anggotanya telah bersepakat untuk menjalin hubungan pemimpin-pengikut. Hubungan yang didasari oleh persetujuan ini tidak 
hanya sebatas kontrak, meskipun disepakati bersama pemimpin tetap harus menunjukkan karakter kepemimpinannya. Sebuah kewajiban dari pihak Dinas UMKM Kota bogor bagi para pedagang di Jalan Dadali untuk memiliki kelompok sebagai syarat administratif. Terdapat beberapa peraturan dan ketentuan yang wajib dipatuhi oleh para pedagang, hal ini membutuhkan peranan seorang pemimpin yang dapat membawa anggotanya untuk mematuhi peraturan. Oleh karena itu, penting untuk diteliti bagaimana derajat kepemimpinan transaksional ketua kelompok pedagang tanaman hias di Jalan Dadali?

Maraknya peminat tanaman hias selama pandemi menyebabkan kenaikan omzet sekitar 40 persen dibandingkan keadaan normal (Gunawan dan Sayaka 2020). Tingginya potensi UMKM tanaman hias selama masa pandemi ini penting untuk melihat kemajuan usaha melalui kinerja usaha tersebut. BPPSDMP (2016) menyatakan pentingnya mengukur kinerja usaha untuk dapat mengetahui kondisi usaha dan melihat seberapa jauh tujuan yang telah tercapai. Tidak hanya itu, mengevaluasi kinerja usaha juga perlu untuk mengidentifikasi masalah-masalah yang dihadapi sehingga dapat digunakan sebagai pertimbangan dalam perencanaan rencana kerja tahap berikutnya. Tingginya minat terhadap tanaman hias bisa jadi memberikan dampak bagi para pedagang tanaman hias di Jalan Dadali yang merupakan salah satu sentra tanaman hias di Kota Bogor. Oleh karena itu menarik untuk diteliti bagaimana kemajuan usaha tanaman hias di Jalan Dadali selama masa pandemi?

Menjalankan usaha secara berkelompok pasti membutuhkan peran seorang pemimpin. Kelompok dagang pedagang tanaman hias di Jalan Dadali tidak mungkin berdiri tanpa adanya sosok pemimpin. Secara langsung maupun tidak langsung sosok pemimpin memiliki berbagai peran dalam mendorong jalannya usaha para pedagang. Terutama pada situasi tak terduga seperti masa pandemi Covid-19. Berdasarkan Tyssen et al. (2014) pemimpin dengan gaya kepemimpinan transaksional cenderung menciptakan kestabilan. Kestabilan merupakan faktor penting bagi usaha para pedagang. Melihat pentingnya peran seorang pemimpin dan keadaan pandemi yang merupakan keadaan yang tidak terduga menarik untuk diteliti bagaimana korelasi kepemimpinan transaksional terhadap kemajuan usaha kelompok dagang tanaman hias di Jalan Dadali?

\section{PENDEKATAN TEORITIS}

\section{Kepemimpinan Transaksional}

Kepemimpinan transaksional adalah kepemimpinan yang didasarkan oleh hubungan pertukaran antara pemimpin dan anggota kelompok dimana hubungannya dinilai dari tujuan dan performa kelompok (İşcan et al. 2014). Yukl (2013) menyatakan bahwa kepemimpinan transaksional dapat melibatkan nilai-nilai seperti kepemimpinan transformatif, tetapi nilainilai yang relevan dengan proses pertukaran, seperti kejujuran, keadilan, tanggung jawab, dan timbal balik. Berdasarkan Bass (1990) pemimpin transaksional memiliki karakteristik yaitu (1) Imbalan Kontingen: Pertukaran kontrak hadiah untuk usaha, menjanjikan hadiah untuk kinerja yang baik, mengakui pencapaian; (2) Manajemen dengan Pengecualian (aktif): memperhatikan dan mencari kesalahan yang menyimpang dari aturan dan standar, mengambil tindakan korektif jika ada kesalahan; (3) Manajemen dengan Pengecualian (pasif): campur tangan dilakukan hanya jika standar tidak terpenuhi; (4) Laissez-Faire: kecenderungan seorang pemimpin untuk menyerahkan tanggung jawab dan menghindari membuat keputusan. Berdasarkan Lewin et al. (1939) Gaya Kepemimpinan Laissez Faire, pemimpin dengan gaya kepemimpinan Laissez Faire sangat memberi kebebasan absolut kepada anggotanya. Pemimpin dengan gaya kepemimpinan Laissez Faire cenderung acuh dan menghindari tanggung jawab dari pengikutnya. Pemimpin sangat tidak mendominasi dalam kegiatan sehingga dominasi dipegang oleh anggotanya. Pemimpin bukan berarti pelit informasi tapi karena kecuekannya ia cenderung hanya memberi informasi pada saat diminta saja.

Berdasarkan Epitropaki dan Martin (2005) sikap korektif pemimpin transaksional yang menentukan standar kepatuhan dan dapat menghukum pengikutnya yang menyimpang membuktikan bahwa pemimpin transaksional mampu untuk mengontrol anggotanya. 
Pemimpin yang memiliki kontrol cenderung memimpin dengan efektif dan stabil. Melakukan usaha dibutuhkan kestabilan agar usaha tersebut terus berjalan. Tyssen et al. (2014) menyatakan bahwa pemimpin yang memimpin secara administratif (pemimpin transaksional) cenderung membuat kestabilan dibandingkan pemimpin visioner (pemimpin transformasional). Penelitian İşcan et al. (2014) telah membuktikan bahwa kepemimpinan secara umum memiliki hubungan positif dengan kinerja usaha. Meskipun kepemimpinan transformatif memiliki pengaruh lebih kuat terhadap kinerja usaha, namun kepemimpinan transaksional juga memiliki pengaruh positif terhadap kinerja usaha meskipun tidak signifikan. Kurniyati (2018) melakukan penelitian tentang pengaruh kepemimpinan terhadap perilaku inovasi karyawan dan kinerja usaha. Hasil dari penelitian tersebut membuktikan bahwa kepemimpinan memiliki pengaruh signifikan terhadap kinerja usaha.

\section{Kemajuan Usaha UMKM}

Kemajuan suatu usaha dapat dilihat dari keberlangsungan dan kinerja usaha tersebut. BPPSDMP (2016) menyebutkan bahwa terdapat dua target yang harus dicapai oleh suatu usaha sebagai tolak ukur kinerja usaha yaitu kepuasan pelanggan dan keuntungan yang didapat. Pada penelitian Munizu (2010) kinerja UKM diukur melalui lima indikator yaitu: (1) Pertumbuhan penjualan; (2) Pertumbuhan tenaga kerja; (3) Pertumbuhan modal; (4) Pertumbuhan laba; (5) Pertumbuhan pasar. Laporan akhir BPS (2007) mengukur kinerja usaha dengan indikator sebagai berikut: (1) Omzet: yaitu besaran nilai produk barang dan jasa yang dihasilkan secara keseluruhan; (2) Output: nilai atas barang dan jasa yang dihasilkan usaha, baik untuk dipasarkan ataupun untuk konsumsi sendiri. Pendapatan yang dimaksud adakah pendapatan dari seluruh kegiatan utama maupun sampingan; (3) Input/ biaya: seluruh pengeluaran usaha dalam rangka produksi selama setahun; (4) Unit usaha: Institusi yang melakukan kegiatan ekonomi; (5) Tenaga kerja: Sumber daya manusia yang membantu proses usaha; (6) Ekspor: perdagangan yang dilakukan dengan pihak luar negri. Kurniyati (2018) dalam penelitiannya mengukur kinerja usaha dengan indikator sebagai berikut: (1) Kemampuan perusahaan dalam meningkatkan efisiensi penggunaan sumber daya manusia yang dimiliki; (2) Kemampuan perusahaan dalam meningkatkan efisiensi penggunaan seluruh waktu yang dimiliki; (3) Kemampuan perusahaan dalam beradaptasi terhadap perubahan; dan (4) Kemampuan perusahaan dalam mencapai target yang telah ditetapkan.

\section{Tren Tanaman Hias di masa Pandemi Covid-19}

Pada 12 Maret 2020, WHO menyatakan bahwa Covid-19 adalah pandemik. Kasus Covid-19 pertama terjadi pada bulan desember 2019 di Kota Wuhan, Cina. Pada bulan maret 2020 dikabarkan bahwa terdapat kasus pertama Covid-19 di Indonesia (Susilo et. al 2020). Penularan virus Covid-19 sangatlah cepat dan mudah. Banyak penularan terjadi antar manusia dengan cara: (1) Menghirup percikan ludah dari bersin atau batuk penderita (droplets) Covid19; (2) Menyentuh mulut atau hidung tanpa mencuci tangan setelah menyentuh benda yang terkontaminasi air liur penderita Covid-19; (3) Kontak erat dengan penderita Covid-19 (Hanoatubun 2020). Sebagai respon adanya pandemi ini pemerintah Indonesia memberikan tanggapan dengan mengeluarkan kebijakan Pembatasan Sosial Berskala Besar (PSBB) yang diatur dalam Peraturan Pemerintah (PP) Nomor 21 Tahun 2020 tentang Pembatasan Sosial Berskala Besar. Selain itu aturan mengenai PSBB juga diatur dalam Keputusan Presiden (Keppres) Nomor 11 Tahun 2020 tentang Penetapan Kedaruratan Kesehatan Masyarakat yang diresmikan pada 31 Maret 2020.

Peraturan Menteri Kesehatan Republik Indonesia Nomor 9 Tahun 2020 tentang Pedoman Pembatasan Sosial Berskala Besar Dalam Rangka Percepatan Penanganan Coronavirus Disease 2019 (Covid-19). Kebijakan dari Menteri Kesehatan Republik Indonesia menjelaskan bahwa penerapan PSBB di Indonesia meliputi: (1) tidak adanya kegiatan di sekolah dan tempat kerja; (2) Pembatasan kegiatan keagamaan; (3) Pembatasan kegiatan di tempat atau fasilitas umum; (4) Pembatasan kegiatan sosial dan budaya; (5) Pembatasan moda transportasi; dan (6) Pembatasan kegiatan lainnya khusus terkait aspek pertahanan dan 
keamanan. Adanya pembatasan sosial menyebabkan terbatasnya aktivitas masyarakat di luar rumah. Hal ini memberikan dampak sosial dan ekonomi bagi masyarakat.

Salah satu pihak yang terdampak pandemi ini adalah pedagang. Pedagang tidak bisa berjualan di tempat ramai karena diterapkannya PSBB. Akibatnya pedagang itu tidak mempunyai penghasilan tetap, Covid-19 secara tidak langsung memperburuk keadaan perekonomian masyarakat di Indonesia (Hanoatubun 2020). Berbeda dengan pedagang lainnya, pedagang tanaman hias tidak mengalami kerugian besar karena tingginya minat masyarakat terhadap tanaman hias selama masa pandemi Covid-19. Gunawan dan Sayaka (2020) menyatakan bahwa sejak pandemi Covid-19 omzet pedagang tanaman hias meningkat hingga 40 persen dari kondisi normal. Hal ini menjadi gambaran perbedaan keadaan pedagang tanaman hias dengan pedagang lainnya.

\section{METODE PELAKSANAAN KEGIATAN}

Penelitian ini menggunakan pendekatan kuantitatif dan didukung dengan data kualitatif. Pendekatan kuantitatif dilaksanakan dengan mengambil data menggunakan kuesioner yang ditanyakan kepada responden. Pendekatan kualitatif dilakukan dengan maksud untuk mengambil data deskriptif yang mendukung data kuantitatif. Data kuantitatif diambil menggunakan teknik wawancara yang dibantu dengan panduan wawancara yang sudah disiapkan sebelum turun ke lapang untuk mengambil data. Penelitian ini merupakan penelitian penjelasan (explanatory atau confirmatory) yang dilakukan untuk menguji sebuah hipotesis. Penelitian pengujian hipotesis merupakan penelitian yang menjelaskan hubungan kausal antara variabel-variabel melalui pengujian hipotesis (Singarimbun dan Effendi 1989).

\section{Lokasi dan Waktu Penelitian}

Penelitian dilakukan di sepanjang Jalan Dadali, Tanah Sareal, Kota Bogor, Jawa Barat. Pemilihan lokasi dilakukan secara purposive atau sengaja dengan pertimbangan: (1) Jalan Dadali adalah salah satu sentra tanaman hias di Kota Bogor; (2) Pedagang tanaman hias di Jalan Dadali merupakan penyewa lahan legal dibawah naungan Dinas UMKM Kota Bogor; dan (3) Paguyuban pedagang di Jalan Dadali yang terdiri dari kurang lebih sebanyak 30 kios yang sudah terbentuk lebih dari 10 tahun.

Kegiatan penelitian dilaksanakan dalam kurun waktu enam bulan yaitu dimulai dari Bulan Februari hingga September 2021.

\section{Teknik Pengumpulan data}

Data yang digunakan dalam penelitian ini adalah data primer dan data sekunder. Data primer didapatkan secara langsung melalui kuesioner yang diisi oleh responden. Data primer didapatkan dari hasil pengisian kuesioner dan wawancara mendalam pada ketua kelompok pedagang tanaman hias dan anggota kelompok dagang tanaman hias. Sebelum dilakukannya pengumpulan data dilapangan dilakukan terlebih dahulu uji validitas dan reliabilitas. Pelaksanaan uji validitas dan reliabilitas menggunakan 10 responden yang menjadi anggota kelompok dagang tanaman hias di tempat lain di Jalan Pajajaran, Kota bogor. Pemilihan tempat uji validitas dan reliabilitas ini dipilih dengan sengaja dengan pertimbangan kemiripan karakteristik yaitu kelompok pedagang yang menjual tanaman hias di Kota Bogor. Uji Reliabilitas dilakukan dengan uji cronbach. Nilai alpha yang didapat dari uji kuesioner penelitian ini sebesar 0.828 yang berarti pertanyaan yang ada pada instrumen penelitian ini reliabel.

\section{Teknik Penentuan Responden dan Informan}

Sumber data dalam penelitian yaitu responden dan juga informan. Subjek yang diteliti adalah pedagang anggota Paguyuban Pedagang Tanaman Hias (PPTH) Arumdalu sebanyak 36 orang. Dengan adanya pembatasan dalam era pandemi saat pengumpulan data berlangsung dan penyesuaian data tertulis dengan kondisi lapang maka jumlah responden yang terlibat dalam penelitian ini yakni sebanyak 30 orang. Unit analisis pada penelitian ini adalah 
individu pedagang kios di Jalan Dadali. Responden yang terpilih adalah pemilik kios maupun anggota keluarga yang terlibat dalam kegiatan usaha yang ditemukan di lapang. Sedangkan, untuk informan adalah sumber data yang memberikan informasi tambahan mengenai topik ataupun tema penelitian yang sedang dikaji. Informan dalam penelitian ini dipilih menggunakan teknik purposive atau dengan pertimbangan tertentu untuk mendapat informasi secara lengkap dan akurat. Informan dalam penelitian ini adalah pihak-pihak yang terlibat dengan kelompok dagang tanaman hias di Jalan Dadali, Tanah Sareal, Kota Bogor, Jawa Barat yaitu Ketua kelompok, Anggota kelompok dan Dinas UMKM.

\section{Teknik Pengolahan dan Analisis Data}

Penelitian ini memiliki dua jenis data yang diolah dan dianalisis, yaitu data kuantitatif dan kualitatif. Data kuantitatif merupakan data yang didapat dari jawaban responden terhadap kuesioner yang diolah dengan menggunakan Microsoft Excel 2019 dan SPSS 25. SPSS 25.0 for windows digunakan untuk membantu dalam pembangunan tabel frekuensi dan uji statistik yang menggunakan Rank Spearman. Uji korelasi Rank Spearman digunakan untuk mengetahui ada atau tidaknya hubungan antar dua variabel yang berskala ordinal dan tanpa prasyarat data terdistribusi normal. Analisis korelasi Rank Spearman dilakukan dengan melihat tingkat kekuatan hubungan variabel, arah hubungan variabel (positif/negatif), dan signifikansi hubungan variabel.

Data kualitatif dari hasil wawancara mendalam dan observasi lapang seputar kepemimpinan dan kemajuan usaha yang didapat dianalisis dan diinterpretasikan sebagai informasi yang mendukung data kuantitatif. Data kualitatif dianalisis menggunakan model Miles dan Huberman melalui tiga tahap yaitu reduksi data, penyajian data, dan verifikasi data (Sugiyono 2019).

\section{HASIL DAN PEMBAHASAN}

\section{Derajat Kepemimpinan Transaksional}

Derajat kepemimpinan transaksional ketua kelompok adalah akumulasi dari tingkat penerapan hukuman dan imbalan, tingkat pengelolaan kelompok dan derajat kepemimpinan laissez faire. Berdasarkan Tabel 1 menunjukkan tingkat kepemimpinan transaksional yang dimiliki ketua kelompok PPTH Arumdalu oleh mayoritas responden sebanyak 26 orang (86,7 persen) menilai tingkat kepemimpinan transaksional ketua berada pada kategori tinggi, empat responden (13,3 persen) menilai tingkat kepemimpinan transaksional ketua kelompok tergolong rendah.

Tabel 1 Jumlah dan persentase responden menurut kepemimpinan transaksional

\begin{tabular}{lrrr}
\hline $\begin{array}{l}\text { Derajat kepemimpinan } \\
\text { transaksional }\end{array}$ & $\begin{array}{l}\text { Jumlah } \\
\text { (n) }\end{array}$ & \multicolumn{2}{c}{$\begin{array}{l}\text { Persentase } \\
(\boldsymbol{\%})\end{array}$} \\
\hline Rendah & 4 & & 13,3 \\
Tinggi & 26 & 86,7 \\
\hline Total & 30 & 100,0 \\
\hline
\end{tabular}

\section{Tingkat Penerapan Imbalan dan hukuman}

Tingkat penerapan imbalan dan hukuman pada PPTH Arumdalu dinilai berdasarkan norma atau peraturan yang telah disepakati bersama. Norma yang ada mencakup peraturan dari Dinas UMKM dan beberapa peraturan lain seputar menjaga kebersihan dan ketertiban di lokasi berjualan. Imbalan yang dimaksud adalah bentuk apresiasi kepada anggota yang aktif dan taat peraturan. 
Tingkat penerapan imbalan dan hukuman berdasarkan hasil yang tertera pada tabel 2 sebanyak 28 responden (93,3 persen) menganggap penerapan imbalan dan hukuman tergolong tinggi. Terdapat dua responden $(6,7$ persen) yang menganggap penerapan imbalan dan hukuman berada di kategori rendah.

Tabel 2 Jumlah dan persentase responden menurut penerapan imbalan dan hukuman

\begin{tabular}{lrr}
\hline $\begin{array}{l}\text { Tingkat Penerapan Imbalan } \\
\text { dan hukuman }\end{array}$ & $\begin{array}{l}\text { Jumlah } \\
(\mathbf{n})\end{array}$ & \multicolumn{2}{c}{$\begin{array}{l}\text { Persentase } \\
(\boldsymbol{\%})\end{array}$} \\
\hline Rendah & 2 & 6,7 \\
Tinggi & 28 & 93,3 \\
\hline Total & $\mathbf{3 0}$ & $\mathbf{1 0 0 , 0}$ \\
\hline
\end{tabular}

Berdasarkan hasil wawancara dengan responden dan informan penerapan imbalan dan hukuman pada PPTH Arumdalu memanglah tergolong tinggi karena ketua seringkali menegur anggotanya yang pasif dan melanggar aturan. Hal ini disebabkan oleh adanya peraturan dari Dinas UMKM yang mewajibkan seluruh pedagang untuk menaati peraturan. Jika ada yang melanggar peraturan akan diberi surat peringatan atau bahkan diputus kontrak dan dilarang berjualan di zona berjualan yang ada. Memberikan apresiasi tidak dilakukan seintens pemberian teguran. Hal ini disebabkan oleh tidak banyak hal yang dapat diapresiasi selain kebersihan, keaktifan dan ketaatan.

\section{Tingkat Pengelolaan Terhadap Kelompok}

Tingkat pengelolaan terhadap kelompok diukur berdasarkan bagaimana ketua PPTH Arumdalu mengawasi anggotanya dalam berkegiatan dengan manajemen eksepsi secara aktif maupun pasif. Pengawasan secara aktif diartikan mengawasi anggota untuk memperhatikan jika ada kesalahan yang terjadi. Pengawasan pasif yang dimaksud adalah pengawasan yang dilakukan jika ketua mendengar atau menemukan adanya penyimpangan saja.

Berdasarkan hasil yang tertera pada tabel 3 tingkat pengelolaan terhadap kelompok tergolong tinggi, mayoritas responden dengan jumlah 27 responden (90 persen). Terdapat tiga responden (10 persen) pada kategori rendah.

Tabel 3 Jumlah dan persentase responden menurut tingkat penerapan pengelolaan terhadap kelompok

\begin{tabular}{lrrr}
\hline $\begin{array}{l}\text { Tingkat } \\
\text { pengelolaan } \\
\text { kelompok }\end{array}$ & $\begin{array}{c}\text { Penerapan } \\
\text { terhadap }\end{array}$ & $\begin{array}{l}\text { Jumlah } \\
(\mathbf{n})\end{array}$ & \multicolumn{2}{l}{$\begin{array}{l}\text { Persentase } \\
(\boldsymbol{\%})\end{array}$} \\
\hline Rendah & & 3 & 10,0 \\
Tinggi & & 27 & 90,0 \\
\hline Total & & $\mathbf{3 0}$ & $\mathbf{1 0 0 , 0}$ \\
\hline
\end{tabular}

Pengelolaan yang dilakukan oleh ketua PPTH Arumdalu adalah berkeliling untuk melihat keadaan dan untuk melihat ketaatan dan ketertiban zona berjualan di Jalan Dadali. Tidak ada jadwal pengawasan yang pasti, ketua PPTH Arumdalu akan berkeliling jika sekiranya beliau sedang memiliki waktu luang. Ketua PPTH Arumdalu melakukan pengawasan bukan untuk mencari kesalahan anggotanya, melainkan beliau berkeliling untuk sekedar mengetahui keadaaan anggotanya. Beliau hanya menegur atau memberi peringatan jika menemukan anggota yang melanggar peraturan saja. Sikap korektif ini didasarkan oleh rasa ingin menjaga anggotanya agar tetap bisa melaksanakan aktivitas usahanya dengan lancar.

Pandemi Covid-19 tidak merubah cara Bapak ST dalam mengelola anggotanya. Pak ST masih berkeliling dengan rutin untuk memastikan anggotanya menerapkan protokol kesehatan untuk menjaga diri dan konsumen. Bila ditemukan pedagang yang lalai dalam menerapkan protokol kesehatan, tanpa segan Pak ST akan menegur anggotanya demi keamanan bersama. Mengelola kelompok ini, Pak ST tidak hanya mengurus persoalan internal saja. Banyak 
perkara eksternal yang perlu diperhatikan seperti hubungan dengan aparat setempat, hubungan dengan preman lokal dan hubungan dengan pemerintahan. Hubungan dengan pihak eksternal ini yang dapat membantu berjalannya aktivitas usaha tanpa ada gangguan dari pihak eksternal. Hubungan dengan pihak pemerintah berhubungan dengan perizinan untuk berjualan. Contohnya sebelum hadirnya Dinas UMKM, izin berjualan didapatkan dari RT/RW setempat dan Kelurahan Tanahsareal. Setelah hadirnya Dinas UMKM jauh mempermudah para pedagang dengan adanya kontrak tahunan sehingga memperkokoh kedudukan para pedagang di lapaknya. Hubungan dengan aparat setempat dibangun dengan mengenal dan mengakrabkan diri dengan Satpol PP dan kepolisian setempat. Citra Jalan Dadali yang dulunya terkenal dengan daerah banyak kriminal kini telah luntur. Hal ini dikarenakan hadirnya para pedagang yang turut menjaga ketertiban di sekitar Jalan Dadali. Hubungan dengan preman lokal dibangun oleh Pak ST untuk menghindari terjadinya tindakan kriminal yang tidak diinginkan. Selain dengan pihak yang sudah disebutkan, Pak ST juga membangun hubungan dengan kelompok pedagang tanaman hias lain di Kota Bogor. Terdapat perkumpulan pedagang tanaman hias Kota Bogor yang anggotanya adalah pedagang tanaman hias di Jalan Dadali, Jalan Pajajaran hingga ke jambu dua dan daerah ertiga. Biasa perkumpulan ini mengadakan pengajian setiap hari rabu dan jumat. Pengajian ini diadakan dengan tujuan keakraban dan untuk memperluas jaringan.

\section{Derajat Kepemimpinan Laissez Faire}

Derajat kepemimpinan laissez faire ketua PPTH Arumdalu dinilai dengan penilaian anggota terhadap penerapan gaya kepemimpinan yang dilakukan oleh ketua. Gaya kepemimpinan laissez faire memiliki ciri ketua yang memberi kebebasan absolut kepada anggotanya. Pemimpin dengan gaya kepemimpinan Laissez Faire cenderung acuh dan menghindari tanggung jawab dari pengikutnya. Pemimpin sangat tidak mendominasi dalam kegiatan sehingga dominasi dipegang oleh anggotanya. Pemimpin bukan berarti pelit informasi tapi karena sifat cueknya ia cenderung hanya memberi informasi pada saat diminta saja.

Berdasarkan hasil yang tertera pada tabel 4 derajat kepemimpinan laissez faire pada paguyuban pedagang tanaman hias Arumdalu tergolong tinggi karena mayoritas responden sebanyak 21 orang (70 persen) berada pada kategori tinggi. Terdapat sembilan responden (30 persen) berada pada kategori rendah.

Tabel 4 Jumlah dan persentase responden menurut derajat kepemimpinan laissez faire

\begin{tabular}{lrr}
\hline $\begin{array}{l}\text { Derajat kepemimpinan } \\
\text { transaksional }\end{array}$ & \multicolumn{1}{l}{$\begin{array}{l}\text { Jumlah } \\
(\mathbf{n})\end{array}$} & Persentase (\%) \\
\hline Rendah & 4 & 13,3 \\
Tinggi & 26 & 86,7 \\
\hline Total & 30 & 100,0 \\
\hline
\end{tabular}

Berdasarkan hasil wawancara dan observasi lapang, ketua PPTH Arumdalu cukup sering menerapkan gaya kepemimpinan laissez faire dengan memberi kebebasan kepada anggotanya dalam kegiatan usahanya masing-masing. Pak ST memberikan wewenang penuh bagi anggotanya dalam menjalankan usahanya masing masing. Hal ini disebabkan oleh tanaman hias di Jalan Dadali adalah usaha keluarga milik pribadi. Masing-masing pemilik memiliki modal pribadi serta supplier dan konsumen yang berbeda-beda. Melepaskan wewenang usaha pada anggota bukan berarti mengabaikan anggota. Beliau kerap mengarahkan anggotanya untuk mengikuti arahan dari Dinas UMKM. Dalam pengambilan keputusan pun dilakukan dengan musyawarah, beliau juga ikut memberikan pendapat dan pandangan untuk kelancaran kegiatan usaha seluruh anggota PPTH Arumdalu.

\section{Kemajuan Usaha Tanaman Hias}

Kemajuan usaha tanaman hias di Jalan Dadali yang diukur dalam penelitian ini adalah selama masa pandemi Covid-19. Selama masa pandemi ini banyak masyarakat yang mulai tertarik untuk merawat tanaman hias untuk menghabiskan waktunya di rumah. Adanya tren tanaman 
hias selama masa pandemi mungkin saja turut memberikan dampak pada keadaan usaha para pedagang tanaman hias yang ada di Jalan Dadali.

Kemajuan usaha merupakan akumulasi peningkatan penjualan, pertambahan tenaga kerja, penambahan modal, peningkatan laba dan perluasan pasar. Berdasarkan hasil yang tertera pada tabel 5 dapat dikatakan mayoritas usaha para pedagang yang tergabung dalam paguyuban pedagang tanaman hias Arumdalu selama masa pandemi Covid-19 tergolong stabil dengan jumlah 28 responden (93,3 persen) dari pedagang merasa usahanya maju. Pedagang dengan keadaan usaha stabil sebanyak 2 responden (6,7 persen).

Tabel 5 Jumlah dan persentase responden menurut kemajuan usaha tanaman hias

\begin{tabular}{lrr}
\hline $\begin{array}{lrr}\text { Kemajuan } \\
\text { Usaha } \\
\text { Tanaman Hias }\end{array}$ & \multicolumn{1}{l}{$\begin{array}{l}\text { Jumlah } \\
(\mathbf{n})\end{array}$} & Persentase (\%) \\
Stabil & 2 & 6,7 \\
Maju & 28 & 93,3 \\
\hline Total & $\mathbf{3 0}$ & $\mathbf{1 0 0 , 0}$ \\
\hline
\end{tabular}

\section{Peningkatan Penjualan}

Peningkatan penjualan dalam penelitian ini diukur dengan ada atau tidaknya pelanggan, intensitas transaksi jual beli di toko dan peningkatan pembeli di toko. Berdasarkan hasil yang tertera pada tabel 6 peningkatan penjualan selama masa pandemi Covid-19 tergolong maju dengan jumlah responden yang ada pada kategori maju sejumlah 25 orang $(83,3$ persen). Responden dengan keadaaan usaha stabil sebanyak lima responden (16,7 persen). Hal ini dapat diartikan selama masa pandemi Covid-19 mayoritas pedagang merasa bahwa penjualan meningkat. Sebagian sisanya merasa penjualan di tokonya tetap stabil.

Tabel 6 Jumlah dan persentase responden menurut peningkatan penjualan

\begin{tabular}{lrr}
\hline $\begin{array}{l}\text { Peningkatan } \\
\text { Penjualan }\end{array}$ & $\begin{array}{l}\text { Jumlah } \\
\text { (n) }\end{array}$ & Persentase (\%) \\
\hline Stabil & 5 & 16,7 \\
Maju & 25 & 83,3 \\
\hline Total & $\mathbf{3 0}$ & $\mathbf{1 0 0 , 0}$ \\
\hline
\end{tabular}

Selama masa pandemi Covid-19 penjualan tanaman hias dapat dikatakan maju karena mulai banyak peminat tanaman hias. Berdasarkan pendapat beberapa pedagang hal ini disebabkan oleh maraknya tren tanaman hias. Tren ini menyebabkan melonjaknya peminat tanaman hias.

Menurut beberapa pedagang, selama masa pandemi selalu ada transaksi penjualan setiap harinya. Transaksi dalam sehari biasa mulai Rp15.000 hingga Rp500.000. Terkadang bisa mencapai jutaan, tergantung tanaman yang terjual. Tanaman yang sering dibeli dengan harga mahal adalah tanaman daun-daunan seperti monstera dan sejenisnya. Hal ini dikarenakan tanaman tersebut yang sedang sedang diminati oleh kalangan masyarakat selama masa pandemi Covid-19. Selain tanaman daun-daunan, tanaman koleksi seperti anggrek dan bonsai juga terjual dengan harga tinggi.

Hari dengan transaksi paling tinggi adalah hari sabtu dan minggu karena ramainya konsumen yang datang diakhir minggu. Banyak berasal dari Jadetabek yang jauh-jauh datang untuk membeli tanaman hias. Banyaknya konsumen dari luar bogor diakibatkan oleh lamanya para pedagang berjualan sehingga daerah Jalan Dadali sudah terkenal sebagai sentra tanaman hias yang terpercaya. Para pedagang masing-masing memiliki pelanggan tetap yang sering dan berulang kali. Lamanya berjualan dan kualitas produk yang dijual oleh pedagang menimbulkan tingginya kepercayaan para konsumen.

\section{Pertambahan Tenaga Kerja}


Pertambahan tenaga kerja diukur dengan keadaan tenaga kerja yang ada sekarang, keinginan untuk menambah tenaga kerja dan kesanggupan untuk menambah tenaga kerja. Keadaan tenaga kerja yang dimaksud adalah keadaan tenaga kerja yang ada sekarang sudah cukup atau belum untuk menjalankan usaha dengan baik. Keinginan menambah tenaga kerja ditanyakan dengan maksud untuk mencari tau apakah akan terjadi penambahan tenaga kerja atau tidak. Kesanggupan untuk menambah tenaga kerja yang dimaksud pada penelitian ini adalah kesiapan dan kesanggupan pengusaha untuk menambah tenaga kerja seperti gaji, pekerjaan dan tugas yang dilakukan. Berdasarkan hasil yang tertera pada tabel 7 pertambahan tenaga kerja pada usaha tanaman hias dianggap stabil dengan sebanyak 18 responden berada pada kategori stabil (60 persen). Terdapat 12 responden (40 persen) dalam kategori maju.

Tabel 7 Jumlah dan persentase responden menurut pertambahan tenaga kerja

\begin{tabular}{lll}
\hline $\begin{array}{l}\text { Pertambahan } \\
\text { tenaga kerja }\end{array}$ & Jumlah (n) & $\begin{array}{l}\text { Persentase } \\
(\boldsymbol{\%})\end{array}$ \\
\hline Stabil & 18 & 60,0 \\
Maju & 12 & 40,0 \\
\hline Total & $\mathbf{3 0}$ & $\mathbf{1 0 0 , 0}$ \\
\hline
\end{tabular}

Selama masa pandemi Covid-19 seluruh usaha tanaman hias di Jalan Dadali tidak menambah tenaga kerja. Terdapat pedagang yang tenaga kerjanya tidak bertambah dan tidak ada kemauan maupun kemampuan untuk menambah tenaga kerja. Ada juga pedagang yang jumlah tenaga kerjanya tetap namun, memiliki kemauan dan kemampuan untuk menambah tenaga kerja. Beberapa pedagang yang mengurangi tenaga kerjanya karena merasa tidak mampu mengeluarkan biaya untuk gaji atau merasa tidak membutuhkan tenaga kerja tambahan. Berdasarkan hasill wawancara, mayoritas pedagang merasa bahwa tenaga kerja yang dimiliki sudah handal dan cukup untuk menggarap usahanya. Mayoritas usaha di Jalan Dadali ini adalah usaha keluarga sehingga tenaga kerja dari keluarga dirasa sudah cukup.

Terdapat berbagai alasan yang membuat pada pedagang memilih untuk tidak menambah tenaga kerjanya. Alasan paling mendasar adalah para pedagang harus mengajari hal-hal mendasar untuk merawat tanaman kepada pekerja baru. Membutuhkan waktu bulanan hingga tahunan bagi seseorang untuk mempelajari tanaman dan cara merawatnya. Hal ini cukup memberatkan pedagang karena mereka perlu untuk mengurus berbagai hal yang bersangkutan dengan usahanya maupun diluar urusan usahanya.

\section{Pertambahan Modal}

Pertambahan modal diukur dengan keadaan permodalan sekarang, penambahan modal dari keuntungan dan keinginan menambah modal dari pinjaman. Keadaan modal sekarang ditanyakan dengan maksud untuk mencari tahu ada atau tidaknya perkembangan modal selama usaha berjalan. Penambahan modal dari keuntungan yang dimaksud pada penelitian ini adalah untuk mengetahui apakah pedagang dapat mengambil keuntungan yang didapat selama pandemi Covid-19 untuk dijadikan modal pengembangan usaha. Keinginan menambah modal dari pinjaman ditanyakan untuk mencari tahu apakah ada keinginan dari pedagang untuk meminjam modal baik dari saudara, koperasi ataupun bank. Adanya keinginan atau keberanian untuk meminjam dianggap menandakan pedagang merasa usahanya sudah cukup stabil. Berdasarkan hasil yang tertera pada tabel 8 pertambahan modal usaha para pedagang dianggap stabil dengan sejumlah 23 responden (76,7 persen) berada pada kategori maju. Terdapat tujuh orang responden (23,3 persen) pada kategori maju.

Tabel 8 Jumlah dan persentase responden menurut pertambahan modal

\begin{tabular}{lll}
\hline $\begin{array}{l}\text { Pertambahan } \\
\text { modal }\end{array}$ & Jumlah (n) & Persentase (\%) \\
\hline Stabil & 7 & 23,3 \\
Maju & 23 & 76,7 \\
\hline Total & $\mathbf{3 0}$ & $\mathbf{1 0 0 , 0}$ \\
\hline
\end{tabular}


Modal awal para pedagang berasal dari tabungannya masing-masing. Para pedagang berkata bahwa modal awal mereka berjualan tidaklah besar. Mereka membangun tokonya secara perlahan. Membeli dan melengkapi ragam tanaman secara perlahan serta membibitkan tanaman yang dimilikinya. Beberapa penjual ada yang memakai uang pinjaman sebagai modal berjualan tetapi, tidak banyak banyak karena mayoritas takut tidak sanggup membayar bunga dan cicilannya. Mayoritas responden mengaku bahwa pendapatan selama pandemi Covid-19 dapat digunakan untuk mengembangkan usahanya. Modal usaha juga kerap bertambah selama usaha berjalan namun, selama pandemi ini karena terjadi lonjakan peminat tanaman hias perputaran modal yang terjadi lebih besar daripada dalam keadaan biasa. Mayoritas pedagang tidak mau atau tidak berminat untuk meminjam modal karena merasa tidak mampu membayar cicilan beserta bunganya.

Meningkatnya penjualan dan laba yang didapat oleh pedagang selama masa pandemi Covid19 ini menyebabkan pedagang mampu mengembangkan usahanya. Contohnya Bapak ST dan beberapa pedagang lainnya dapat menambah berbagai tanaman dan ornamen taman. Berdasarkan pendapat Bapak ST terdapat beberapa pedagang yang dapat membeli kendaraan setelah minat masyarakat pada tanaman hias meningkat.

\section{Peningkatan Laba}

Peningkatan laba diukur dengan ada atau tidaknya peningkatan keuntungan penjualan, stabilitas kenaikan keuntungan penjualan dan target keuntungan yang dimiliki penjual. Ada atau tidaknya peningkatan keuntungan ditanyakan untuk mencari tahu ada atau tidaknya peningkatan keuntungan penjualan tanaman hias selama masa pandemi Covid-19. Stabilitas kenaikan keuntungan penjualan ditanyakan untuk mencari tahu keadaan dan pola kenaikan keuntungan penjualan apakah selalu meningkat atau menurun. Target keuntungan ditanyakan untuk mengetahui apakah keuntungan selama pandemi Covid-19 ini kurang dari target, memenuhi atau bahkan melebihi. Berdasarkan hasil yang tertera pada tabel 9 peningkatan laba selama pandemi Covid-19 dapat dikatakan meningkat dengan sebanyak 16 responden (53,3 persen) berada pada kategori maju. Sebanyak 14 responden (46,7 persen) berada pada kategori stabil.

Tabel 9 Jumlah dan persentase responden menurut peningkatan laba

\begin{tabular}{lll}
\hline $\begin{array}{l}\text { Peningkatan } \\
\text { Laba }\end{array}$ & Jumlah (n) & Persentase (\%) \\
\hline Stabil & 14 & 46,7 \\
Maju & 16 & 53,3 \\
\hline Total & $\mathbf{3 0}$ & $\mathbf{1 0 0 , 0}$ \\
\hline
\end{tabular}

Keuntungan yang didapat para pedagang cenderung meningkat karena kenaikan harga akibat tren dan minat yang melonjak mengakibatkan peningkatan harga bibit maupun tanaman jadi dari supplier. Membicarakan jenis tanaman yang menguntungkan, tidak dapat dispesifikkan pada satu tanaman saja. Seiring bergantinya tren tanaman yang menguntungkan pun berganti. Contohnya pada masa pandemi ini tanaman yang paling banyak diminati adalah berbagai jenis monstera yang dapat dipelihara di dalam ruangan. Beberapa pedagang tidak hanya berjualan tanaman hias biasa, ada beberapa pedagang yang juga menjual tanaman yang dikoleksi dengan harga tinggi seperti bonsai dan anggrek. Tanaman koleksi yang terdapat komunitas seperti anggrek dan bonsai cenderung lebih stabil peminatnya dibandingkan dengan tanaman hias biasa yang peminatnya mengikuti tren. Terjadinya peningkatan laba di awal pandemi tidaklah bertahan lama karena sempat terjadi penurunan pembeli sehingga pemasukan bagi para pedagang pun juga ikut menurun.

Naiknya minat masyarakat dan tren tanaman hias menyebabkan meningkatnya harga beberapa tanaman yang tinggi peminatnya seperti jenis monstera. Meningkatnya harga juga diakibatkan harga dari supplier yang tinggi namun, keuntungan yang didapat cukup tinggi 
karena harga pasar yang meningkat pesat. Peningkatan keuntungan ini sangat bergantung dengan tren yang ada. Selama tren tinggi pada bulan agustus hingga desember 2020, laba yang didapat tergolong tinggi. Memasuki tahun 2021 tren perlahan menurun sehingga keuntungan yang didapat berangsur-angsur ikut turun. Selama bulan puasa (April-Mei 2021) konsumen yang datang untuk membeli menurun sehingga keuntungan yang didapat juga menurun.

\section{Perluasan Pasar}

Perluasan pasar diukur dengan ada atau tidaknya cabang usaha, promosi online dan transaksi diluar jabodetabek. Adanya cabang usaha dapat dikatakan sebagai kemajuan dalam usaha, maka ada atau tidaknya cabang usaha menjadi salah satu pengukur perluasan pasar. Promosi online sangat dibutuhkan selama masa pandemi Covid-19. Promosi yang dimaksud adalah menyebarkan informasi toko, barang jualan dan sebagainya melalui platform media sosial maupun e-commerce. Selain promosi di sosial media promosi dengan mengontak pelanggan secara langsung juga dipertimbangkan. Transaksi diluar jabodetabek juga menjadi salah satu pengukur perluasan pasar karena semakin beragam kota yang menjalankan transaksi dengan toko maka semakin luas pasar toko tersebut.

Berdasarkan hasil yang tertera pada tabel 10 perluasan pasar usaha para pedagang selama pandemic Covid-19 tergolong stabil dengan sebanyak 20 responden (66,7 persen) pada kategori tersebut. Terdapat 10 responden (66,7persen) yang berada pada kategori maju.

Tabel 10 Jumlah dan persentase responden menurut perluasan pasar

\begin{tabular}{lll}
\hline $\begin{array}{l}\text { Perluasan } \\
\text { Pasar }\end{array}$ & Jumlah (n) & Persentase (\%) \\
\hline Stabil & 20 & 66,7 \\
Maju & 10 & 33,3 \\
\hline Total & $\mathbf{3 0}$ & $\mathbf{1 0 0 , 0}$ \\
\hline
\end{tabular}

Masih banyak pedagang tidak memanfaatkan promosi online dan hanya berjualan di lapaknya saja. Beberapa sudah memanfaatkan sistem pesan personal dan beberapa sudah memaksimalkan promosi online dengan memasarkan produk dagang di media sosial. Mayoritas pedagang enggan untuk menggunakan promosi online karena takut pelanggan merasa kecewa jika tidak sesuai dengan gambar yang diunggah. Pedagang yang tidak memanfaatkan promosi online adalah pedagang dengan usia yang tergolong tua. Pedagang yang memanfaatkan media promosi online cenderung berusia lebih muda.

Pedagang yang memiliki banyak pelanggan tetap mayoritas mengandalkan pesan personal kepada para pelanggan. Hal ini sudah dilakukan dari sebelum masa pandemi Covid-19. Hal ini cukup efektif untuk memasarkan tanaman baru. Beberapa pedagang sudah mampu memasarkan tanamannya hingga luar Pulau Jawa namun, selama masa pandemi tidak banyak transaksi keluar kota. Terdapat pedagang yang tidak menjual tanaman ke luar kota dengan alasan kurang paham cara mengemas tanaman hias dengan aman untuk dikirimkan melalui kargo ataupun jasa kirim paket. Selain itu, mengirim tanaman ke luar kota membutuhkan surat izin yang proses pembuatannya cukup rumit. Prosedur pengiriman yang membutuhkan banyak tenaga dan waktu membuat beberapa pedagang enggan untuk melakukan perdagangan keluar kota.

\section{Hubungan Derajat Kepemimpinan Transaksional dan Tingkat Kemajuan Usaha Tanaman Hias}

Berdasarkan hasil uji korelasi Rank spearman antara variabel derajat kepemimpinan transaksional dan tingkat kemajuan usaha, kedua variabel berhubungan positif dengan koefisien kuat sebesar 0,681 . Kedua variabel berkorelasi dengan nilai signifikansi sebesar 0,000 (Nilai Sig. (2-tailed) $0,000<0,05$ ) dapat dikatakan korelasi antara kedua variabel tersebut signifikan. 
Tabel 11 Tabulasi silang Kepemimpinan Transaksional dan Kemajuan Usaha Tanaman Hias

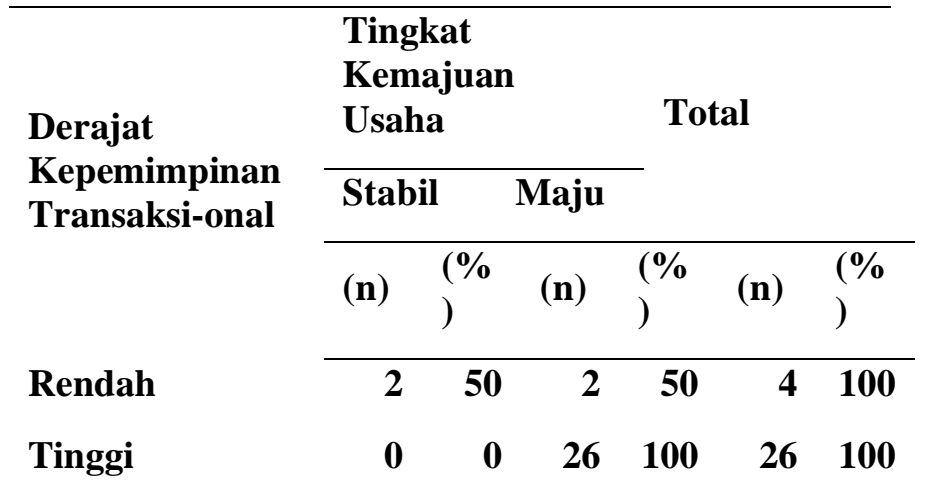

terlihat bahwa semakin tinggi derajat kepemimpinan transaksional semakin maju usaha para pedagang tanaman hias. Hal ini membuktikan bahwa kepemimpinan transaksional cocok untuk menjaga kestabilan dan memajukan suatu kelompok dalam keadaan yang tidak tentu seperti pandemi. Kemajuan usaha para pedagang ini adalah sebuah hasil dari konsistensi ketua dan anggota untuk menaati peraturan sehingga kegiatan usaha dapat berjalan normal dalam keadaan pandemi.

Usia kelompok yang sudah cukup lama pun menimbulkan kepercayaan tinggi di antara ketua dan anggotanya. Anggota sudah cukup paham akan konsekuensi yang diterima jika tidak menaati aturan seperti teguran bahkan tindak lanjut dari dinas. Berdasarkan keadaan lapang, anggota kelompok selalu menaati aturan dan nasihat dari ketua. Hanya hal-hal yang bersangkutan dengan finansial yang kadang menimbulkan sedikit pertikaian. Contohnya adalah penarikan uang kas selain uang kebersihan atau uang santunan. Meskipun ketua memimpin dengan tegas, tetap ada beberapa kendala yang tidak bisa diselesaikan dengan ketegasan seperti masalah finansial.

Aksi-aksi yang dilakukan oleh ketua PPTH Arumdalu ini terbukti dapat mendorong kelompok untuk memajukan usahanya. Beberapa pertikaian yang tidak terhindarkan juga dapat diselesaikan dengan kesepakatan bersama. Meskipun solidaritas dan kekeluargaan para pedagang sangat tinggi, mereka sangat tegas dalam masalah usaha. Hubungan sebatas ketua dan pengikut tanpa ikut campur diluar hak dan kewajiban sangatlah mencerminkan hubungan antar pedagang di paguyuban ini. Para pedagang anggota paguyuban diberikan kebebasan dan kuasa masing-masing dalam mengelola usahanya. Ketua paguyuban tidak mencampuri urusan usaha anggotanya selama kegiatan tersebut tidak merugikan kepentingan bersama. Sudah sedikit dijelaskan pada bab enam, tepatnya bagian derajat kepemimpinan laissez faire. Ketua PPTH Arumdalu selalu membebaskan anggotanya dalam kegiatan usahanya masing-masing.

Meskipun berasal dari kampung halaman yang beragam, mayoritas pedagang beretnis madura. Hal ini yang menyebabkan kokohnya kelompok untuk bertahan di area tersebut tanpa gangguan. Etnisitas memegang peran besar dalam mempertahankan posisi para pedagang tanaman hias. Adanya monopoli pasar oleh penjual dengan etnis madura mampu melawan pesaing yang ingin masuk ke pasar tanaman hias di Kota Bogor. Kesamaan latar belakang etnis dan kampung halaman menjadi kekuatan kelompok ini. Hal ini memudahakan ketua dalam memimpin karena terdapat kesamaan latar belakang sosial budaya. Seluruh pedagang tanaman hias di Kota Bogor ini tergabung dalam satu kelompok yang rutin mengadakan perkumpulan tiap minggu untuk mengaji dan berdiskusi. Terdapat berbagai hal yang didiskusikan dalam pertemuan ini, contohnya rencana kebijakan yang diberikan oleh Dinas UMKM untuk menarifkan biaya sewa lapak yang selama ini tidak ada. Forum ini dimanfaatkan untuk mendiskusikan hal-hal mendasar hingga krusial yang bersangkutan dengan aktivitas usaha para pedagang tanaman hias.

Ketua pada paguyuban ini merupakan tokoh yang bukan untuk sekedar berbisnis tapi untuk membentuk jaringan untuk memperkuat posisi dan keamanan seperti ke apparat, dinas dan pemerintah sekitar. Peran yang dilakukan oleh ketua PPTH Arumdalu ini lebih tepat jika 
diumpamakan sebagai jembatan antara pihak eksternal seperti Dinas UMKM, preman lokal dan aparat setempat dengan seluruh pedagang tanaman hias di Jalan Dadali. Terbentuknya kelompok dan adanya pemimpin ini ditujukan untuk mempermudah jalur informasi secara internal (antar pedagang) maupun eksternal (dengan dinas dan pihak lainnya). Tugas yang dilakukan oleh ketua PPTH Arumdalu dapat disamakan dengan koordinator lapang yang bertugas untuk menjaga ketertiban dan keberlangsungan kegiatan usaha di Jalan Dadali. Hubungan timbal balik antara ketua dan anggota paguyuban sangat dibutuhkan untuk kelancaran usaha. Terutama dalam masalah ketertiban dimana seluruh anggota wajib mematuhi seluruh peraturan agar kegiatan usaha mereka berjalan lancar. Ketua memberikan apresiasi dan perhatian maka anggota menaati dan patuh pada peraturan. Ketegasan yang diberikan ketua PPTH Arumdalu dalam memimpin kelompoknya selama ini terbukti dapat menertibkan anggota sehingga kegiatan usaha dapat berjalan dengan lancar. Melihat keadaan usaha para pedagang yang mengalami kemajuan selama masa pandemi ini menunjukkan bahwa dengan memiliki pemimpin dengan gaya kepemimpinan transaksional dapat mempertahankan bahkan mengembangkan usaha para pedagang yang ada di Jalan Dadali.

Fenomena kemajuan usaha tanaman hias ini adalah sisi positif dari adanya pandemi Covid-19. Saat komoditas lain mengalami penurunan, tanaman hias yang termasuk dalam hobi dan musiman mengalami peningkatan. Akibat dari perubahan pola hidup masyarakat yang memerlukan hobi sebagai pelepas stress selama terjebak di rumah. Berdasarkan hasil wawancara dan observasi lapang, terdapat faktor lainnya yang lebih mempengaruhi kemajuan usaha tanaman hias yaitu minat pelanggan dan tren. Hal ini dikuatkan dengan fenomena meningkatnya penjualan dan meningkatnya keuntungan yang hanya terjadi di paruh waktu akhir tahun 2020. Waktu tersebut bertepatan dengan tingginya tren tanaman hias dan minat masyarakat terhadap tanaman hias sebagai pelepas stress saat menghabiskan harinya di rumah.

Kegiatan usaha pedagang tanaman hias sangat bergantung dengan minat masyarakat dan juga tren tanaman hias. Setelah tren tanaman hias mulai turun, usaha para pedagang juga ikut turun. Pada saat tren ini terjadi, mayoritas pedagang mengaku bahwa terdapat peningkatan penjualan, pendapatan dan juga laba. Seperti yang sudah dijelaskan pada pembahasan perluasan pasar, mayoritas pedagang belum memaksimalkan pemasaran sehingga penjualan masih sangat tergantung bagaimana tren yang membawa minat pembeli. Jika pedagang dapat memaksimalkan pemasaran, ketergantungan usaha kepada tren akan berkurang sehingga usaha dapat maju lebih baik dan berkelanjutan. Dimasa yang penuh dengan kemajuan teknologi ini, banyak muncul pesaing baru yang menawarkan kemudahan bagi konsumen untuk berbelanja secara online. Namun, para pedagang tanaman hias di Jalan Dadali dapat berjualan secara konvensional dengan lancar. Konsumen yang datang untuk berbelanja datang dari berbagai daerah seperti Jadetabek. Hal ini timbul akibat tingginya kepercayaan konsumen kepada para pedagang tanaman hias di Jalan Dadali. Lama waktu berjualan memiliki peran besar untuk membangun kepercayaan dari para konsumen. Kekonsistenan para pedagang untuk menjaga kualitas produk selama bertahun-tahun membuat citra yang baik bagi para pedagang tanaman hias di Jalan Dadali.

\section{KESIMPULAN}

Berdasarkan hasil dari penelitian mengenai Kepemimpinan Transaksional dan Kemajuan Usaha Kelompok Pedagang Tanaman Hias dapat disimpulkan bahwa: (1) Derajat kepemimpinan transaksional ketua PPTH Arumdalu tergolong dalam kategori tinggi. Hal ini didukung dengan cara ketua PPTH Arumdalu dalam menerapkan imbalan dan hukuman, pengelolaan kelompok dan memimpin dengan memberi kebebasan pada anggotanya (laissez faire). Ketegasan ketua dalam mengawasi anggotanya dapat membuat anggotanya taat dan patuh terhadap peraturan yang ada. Anggota pun paham akan kewajibannya dan menaati seluruh aturan untuk menghindari teguran. Ketua lepas tangan dan memberi wewenang penuh pada masing masing pemilik usaha untuk mengatur usahanya. Selama tindakan atau keputusan pemilik usaha tidak merugikan kelompok dan pelanggan ketua tidak memiliki hak untuk ikut campur. Ketua tidak hanya mengelola internal kelompok. Masalah yang berkaitan 
dengan hubungan kelompok dengan pihak eksternal juga menjadi tanggung jawab ketua. Kesamaan etnisitas antara pemimpin dengan anggota memiliki peran yang cukup besar dalam keberlangsungan ketua memimpin kelompok dagang ini; (2) Usaha Tanaman Hias anggota PPTH Arumdalu tergolong maju selama pandemi Covid-19. Hal ini didukung oleh keadaan penjualan, permodalan, tenaga kerja, dan laba para pedagang tanaman hias anggota PPTH Arumdalu yang maju selama pandemi Covid-19. Pasar penjualan pada pedagang selama masa pandemi berada pada keadaan stabil. Usaha para pedagang sempat mengalami kemajuan sementara di paruh akhir tahun 2020 saat tingginya minat masyarakat terhadap tanaman hias akibat adanya tren. Kemajuan itu tidak bertahan lama dan usaha para pedagang kembali ke keadaan normal setelah tren mereda. Meskipun mengalami fluktuasi, keadaan usaha secara keseluruhan tetap mengalami kemajuan. Ditemukan faktor lain yang turut memiliki peran terhadap kemajuan usaha tanaman hias yaitu tren dan minat masyarakat. Saat ini, keadaan usaha para pedagang hias masih bergantung pada tren dan minat masyarakat; dan (3) Terbukti derajat kepemimpinan transaksional berkorelasi signifikan dengan kemajuan usaha tanaman hias. Kepemimpinan transaksional dan kemajuan usaha berhubungan positif dengan kekuatan kuat. Terlihat dari hasil penelitian yaitu semakin tinggi kepemimpinan transaksional ketua paguyuban maka semakin maju usaha para anggota. Meskipun ketua memimpin dengan gaya transaksional, etnisitas para pedagang turut memberikan kontribusi dalam memperkuat posisi pedagang di pasar maupun di lokasi berjualan. Etnisitas yang memonopoli pasar tanaman hias mampu bertahan tanpa adanya pesaing dan gangguan selama berjualan.

\section{Saran}

Saran yang dapat direkomendasikan berdasarkan penelitian ini diantaranya adalah: (1) Ketua paguyuban pedagang tanaman hias sebaiknya terus mempertahankan cara memimpinnya. Namun, ketua harus dapat menyesuaikan cara memimpin dengan keadaan yang sedang dihadapi; (2) Para pedagang tanaman hias dapat memperluas pasar dengan memanfaatkan promosi online dan memantau tren. Hal ini perlu dilakukan untuk menarik minat masyarakat luas terhadap tanaman hias agar dapat mengembangkan usahanya lebih baik; (3) Perlu dilakukan penelitian lebih lanjut tentang kemajuan usaha tanaman hias yang dikaitkan dengan tren dan minat masyarakat; dan (4) Perlu dilakukan penelitian lebih lanjut tentang peranan etnisitas terhadap kepemimpinan dan kemajuan usaha para pedagang.

\section{DAFTAR PUSTAKA}

Andari. 2019. Pengaruh Gaya Kepemimpinan Transaksional dan Motivasi Terhadap Kinerja Karyawan PT Trans Retail Indonesia Serang. J Manaj. 9(1):68-82. [Internet]. [Diakses pada 2021 Februari 28] Tersedia pada: https://doi.org/10.30656/jm.v9i1.1485

Arifudin O. 2020. Pengaruh Gaya Kepemimpinan Transformasional dan Transaksional dengan Kinerja. J Ilm MEA (Manajemen, Ekon dan Akuntansi). 4(3):178-187. [Internet]. [Diakses pada 2021 Februari 28] Tersedia pada: http://dx.doi.org/10.36467/makro.2020.05.02.05

Bass BM. 1990. From transactional to determining for a group of loyal transformational leadership: learning to followers, the direction, pace, and share vision. Organ Dyn. 18(3):19-32. [Internet]. [Diakses pada 2021 Februari 28] Tersedia pada: https://www.mcgill.ca/engage/files/engage/transformational_leadership_bass_1990.pd $\underline{f}$

[BKKBN]. Badan Kependudukan dan Keluarga Berencana Nasional. 2011. Batasan dan Pengertian MDK. [Internet]. [Diakses pada 2021 Juni 26]. http://aplikasi.bkkbn.go.id/mdk/BatasanMDK.aspx

BPS. 2007. Pengukuran dan Analisis Ekonomi Kinerja Penyerapan Tenaga Kerja, Nilai Tambah dan Ekspor UKM Serta Peranannya Menurut Harga Konstan dan Berlaku. 
[Internet]. [Diakses pada $2021 \quad$ Februari 27]. https://www.bps.go.id/publication/2008/07/08/9e4da97c04eeaa613c925fa1/pengukura n-dan-analisis-ekonomi-kinerja-penyerapan-tenaga-kerja-nilai-tambah-ukm-sertaperanannya-menurut-harga-konstan-dan-harga-berlaku-tahun-2007.html

BPPSDMP. 2016. Badan Penyuluhan dan Pengembangan Sumber Daya Manusia Pertanian. Modul Pemnumbuhan Wirausaha Muda Pertanian (PWPM).

Cote R. 2017. A Comparison of Leadership Theories in an Organizational Environment. Int J Bus Adm. [Internet]. [Diakses pada 2021 Februari 28]. doi:10.5430/ijba.v8n5p28.

Epitropaki O, Martin R. 2005. The moderating role of individual differences in the relation between transformational/transactional leadership perceptions and organizational identification. Leadersh Q. 16(4):569-589. doi:10.1016/j.leaqua.2005.06.005.

Epitropaki O, Martin R. 2013. Transformational-transactional leadership and upward influence: The role of Relative Leader-Member Exchanges (RLMX) and Perceived Organizational Support (POS). Leadersh Q. 24(2):299-315. doi:10.1016/J.LEAQUA.2012.11.007.

Gunawan E, Sayaka B. 2020. Imbas pandemi Covid-19, bisnis tanaman hias naik daun - Pusat Sosial Ekonomi dan Kebijakan Pertanian. Kementrian Pertan. [Internet]. [Diakses pada 2021 Februari 28]. http://pse.litbang.pertanian.go.id/ind/index.php/covid-19/beritacovid19/583-imbas-pandemi-covid-19-bisnis-tanaman-hias-naik-daun

Hanoatubun S. 2020. Dampak Covid-19 Terhadap Perekonomian Indonesia. [Internet]. [Dinduh pada 2021 Mar 27]. Tersedia pada: https://ummaspul.ejournal.id/Edupsycouns/article/view/423/240

İşcan ÖF, Ersarı G, Naktiyok A. 2014. Effect of Leadership Style on Perceived Organizational Performance and Innovation: The Role of Transformational Leadership Beyond the Impact of Transactional Leadership - An Application among Turkish SME's. Procedia - Soc Behav Sci. 150:881-889. [Internet]. [Diakses pada 2021 Februari 28]. doi:10.1016/j.sbspro.2014.09.097.

[KemenkesRI] Kementerian Kesehatan Republik Indonesia. 2020. Peraturan Nomor 9 tentang Pedoman Pembatasan Sosial Berskala Besar Dalam Rangka Percepatan Penanganan Corona Virus Disease 2019 (Covid-19).

[Keppres]. Keputusan Presiden. 2020. Nomor 11 tentang Penetapan Kedaruratan Kesehatan Masyarakat

Kurniyati NN. 2018. Pengaruh gaya kepemimpinan transformasional terhadap perilaku inovatif karyawan dan kinerja UMKM kecamatan kraton yogyakarta. J Solusi. 13(1):31-54. [Internet]. [Diakses pada 2021 Februari 28]. https://doi.org/10.51277/keb.v13i1.21

Lewin K, Lippitt R, White RK. 1939. Patterns of Aggressive Behavior in Experimentally Created "Social Climates", The Journal of Social Psychology.10(2): 269-299. Internet]. [Diakses pada $2021 \quad$ Februari http://dx.doi.org/10.1080/00224545.1939.9713366

Munizu M. 2010. Pengaruh faktor-faktor eksternal dan internal terhadap kinerja usaha mikro dan kecil (UMK) di Sulawesi Selatan. J Manaj

Nurdiyas. 2009. Gaya Kepemimpinan dalam Memotivasi Kerja Pegawai. Ed ke-1 Widayanti S, editor. Padang: Balai Besar Pendidikan dan Pelatihan Kesejahteraan Sosial Padang.

[PP]. Peraturan Pemerinah. 2020. Pembatasan Sosial Berskala Besar

[RI] Republik Indonesia. 2013. Peraturan Pemerintah tentang Pelaksanaan Undang-undang Nomor 20 Tahun 2008 tentang Usaha Mikro Kecil dan Menengah. (ID). [Internet]. [Diakses pada 2021 Maret 1]. https://peraturan.bpk.go.id/Home/Details/5349/pp-no- 
17-tahun-

2013\#: :text=PP\%20No.\%2017\%20Tahun\%202013,dan\%20Menengah\%20\%5BJDIH $\% 20 \mathrm{BPK} \% 20 \mathrm{RI} \% 5 \mathrm{D}$

Sugiyono. 2019. Metode Penelitian Kuantitatif, Kualitatif dan R\&D. Edisi dua. Sutopo, editor. Bandung: Alfabeta.

Susilo A, Rumende CM, Pitoyo CW, Santoso WD, Yulianti M, Sinto R, Singh G, Nainggolan L, Nelwan EJ, Khie L, et al. 2020. Coronavirus Disease 2019: Tinjauan Literatur Terkini Coronavirus Disease 2019: Review of Current Literatures. 7(1):45-67. [Internet]. [Diakses pada 2021 Mar 27]. http://dx.doi.org/10.7454/jpdi.v7i1.415

Tyssen AK, Wald A, Spieth P. 2014. The challenge of transactional and transformational leadership in projects. Int $J$ Proj Manag. 32(3):365-375. doi:10.1016/j.ijproman.2013.05.010.

[WHO] World Health Organization. 2020. Covid 19 Public Health Emergency of International Concern (PHEIC). Global Research and Innovation Forum: Towards a Research Road Map.

Yukl G. 2013. Leadership in Organizations, 8th Edition. Eight edit. New Jersey: Pearson Education, Inc. 